\title{
Do Smart City Policies Work?
}

\author{
Andrea Caragliu and Chiara Del Bo
}

\begin{abstract}
Smart City policies have attracted significant funding over the last few years. However, only less evidence is available of their impact on urban economic performance. In this paper, we look at the urban growth and innovation impact of Smart City policies, exploiting a dataset collected for these analyses comprising data on Smart City characteristics of 309 European metro areas, Smart City policy intensity, along with the urban growth and innovation outputs. Economic growth is measured as real GDP increases, while innovation is captured by patent applications to the European Patent Office, both measures being calculated between 2008 and 2013. Patent counts include technologically narrower classes, namely high-tech, ICT and specific Smart City technology patent applications. Instrumental variables and propensity score matching estimates suggest that cities engaging in Smart City policies more than the EU average tend to grow faster and patent more intensively.
\end{abstract}

Keywords Smart city · Program evaluation · Instrumental variables · Propensity score matching

JEL Classification Codes $\mathrm{R} 11 \cdot \mathrm{R} 12 \cdot \mathrm{H} 43$

This paper presents an original synthesis of the work carried out by the authors. Particularly, empirical analyses have been originally described in Caragliu and Del Bo $(2018,2019)$.

\footnotetext{
A. Caragliu ( $\varangle)$

Architecture, Built Environment and Construction Engineering-ABC Department, Politecnico di Milano, Milan, Italy

e-mail: andrea.caragliu@polimi.it

C. Del Bo

Department of Economics, Management and Quantitative Methods-DEMM, Università degli Studi di Milano, Milan, Italy

e-mail: chiara.delbo@unimi.it

(C) The Author(s) 2020

B. Daniotti et al. (eds.), Digital Transformation of the Design, Construction and Management Processes of the Built Environment, Research for Development, https://doi.org/10.1007/978-3-030-33570-0_14
} 


\section{Introduction}

The literature on Smart Cities has achieved vast academic and policy success, with a fast acceleration of scientific production over the past few years. The pervasive presence of information and communication technologies (henceforth, ICTs) in the present-day cities and the involvement of urban dwellers in collecting, sharing and exploiting information collected by sensors has elicited a debate cutting across different disciplines (Fig. 1), with a major focus on engineering, computer science and telecommunication studies.

This literature has also been criticized on the grounds of the heterogeneity in the type of scientific output, which often comprises gray literature and unpublished manuscripts as shown in Table 1.

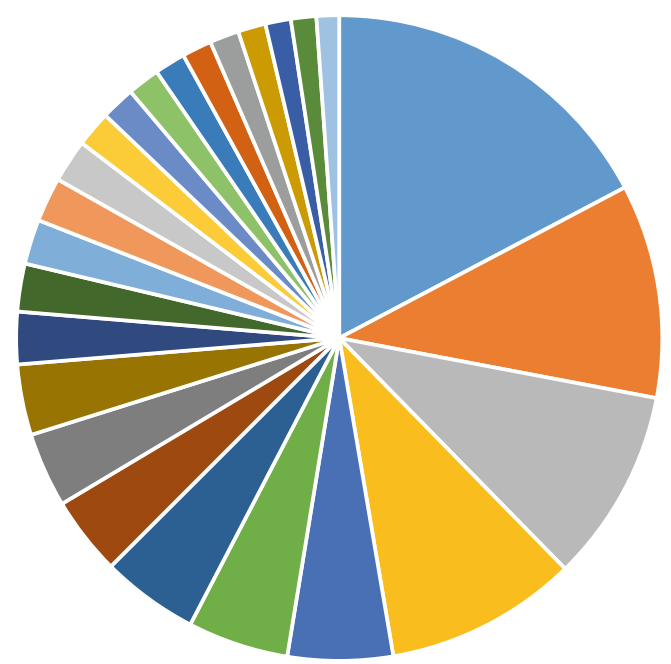

- ENGINEERING ELECTRICAL ELECTRONIC

- TELECOMMUNICATIONS

- COMPUTER SCIENCE ARTIFICIAL INTELLIGENCE

- URBAN STUDIES

- computer science haRdWARE ARChITECTURE

- COMPUTER SCIENCE SOFTWARE ENGINEERING

- ENVIRONMENTAL STUDIES

- ENVIRONMENTAL SCIENCES

- ENGINEERING CIVIL

- INSTRUMENTS INSTRUMENTATION

- GEOGRAPHY

- BUSINESS

- TRANSPORTATION
- COMPUTER SCIENCE INFORMATION SYSTEMS

- COMPUTER SCIENCE THEORY METHODS

- COMPUTER SCIENCE INTERDISCIPLINARY APPLICATIONS

- GREEN SUSTAINABLE SCIENCE TECHNOLOGY

- ENERGY FuELS

- REgional uRBan PLANNING

- TRANSPORTATION SCIENCE TECHNOLOGY

- AUTOMATION CONTROL SYSTEMS

- ENGINEERING MULTIDISCIPLINARY

- MANAGEMENT

- ECONOMICS

- CONSTRUCTION BUILDING TECHNOLOGY

Fig. 1 Scientific outputs on Smart Cities divided by scientific discipline as of May 2019. Source Author's elaboration on the basis of Web of Science (WoS) raw data. Search made on May 2, 2019. Search strategy: «Smart cit*» 
Table 1 Typologies of scientific outputs on Smart Cities as of May 2019

\begin{tabular}{l|c|l}
\hline Document types & Record count (May 2019) & $\%$ \\
\hline Proceedings paper & 6490 & $49.34 \%$ \\
\hline Article & 5347 & $40.65 \%$ \\
\hline Book chapter & 612 & $4.65 \%$ \\
\hline Editorial material & 301 & $2.29 \%$ \\
\hline Review & 243 & $1.85 \%$ \\
\hline Book review & 62 & $0.47 \%$ \\
\hline Book & 34 & $0.26 \%$ \\
\hline News item & 25 & $0.19 \%$ \\
\hline Correction & 10 & $0.08 \%$ \\
\hline Letter & 8 & $0.06 \%$ \\
\hline Data paper & 7 & $0.05 \%$ \\
\hline Meeting abstract & 7 & $0.05 \%$ \\
\hline Early access & 3 & $0.02 \%$ \\
\hline Retracted publication & 2 & $0.02 \%$ \\
\hline Biographical item & 1 & $0.01 \%$ \\
\hline Poetry & 1 & $0.01 \%$ \\
\hline Reprint & 1 & $0.01 \%$ \\
\hline Total & 13,154 & 1 \\
\hline Source Aury & &
\end{tabular}

Source Author's elaboration on the basis of WoS raw data. Search made on May 2, 2019. Search strategy: «Smart cit*»

Yet, the interest in Smart Cities seems far from vanishing. In fact, if anything, research on Smart Cities is increasingly being carried out across all major universities, with a growth of scientific impact, ${ }^{1}$ which testifies the importance of the topic from both an academic and a policy perspective.

Consequently, Smart Cities have drawn the attention of countless policymakers at all administrative levels, shaping policies aimed at making cities smarter. Relevant funding has been provided by bodies such as the European Commission (European innovation partnership on smart cities and communities; henceforth, SCC), European Investment Bank, and countless States and regional Authorities. Yet, the landscape of policy assessment is rather scant.

Within this framework, this paper offers a synthesis of the quantitative research we carried out on the impact of Smart City policies on urban economic performance. The paper is structured as follows. Section 2 briefly summarizes the debate on the definition of Smart Cities, culminating with the one provided in Caragliu et al. (2011) which underlies all the empirical contributions discussed later. While in Sect. 3 a brief recap of the way Smart City policies have been implemented and translated into data is presented. Section 4 discusses the empirical methodologies for policy assessment adopted in the empirical estimates, which are synthesized in Sect. 5, and the dataset collected for our analyses. Finally, Sect. 6 draws a number of conclusions.

\footnotetext{
${ }^{1}$ Works satisfying the WoS search strategy used for Fig. 1 and Table 1 suggest that roughly $50 \%$ of all (12,395) WoS entries have been published between 2017 and 2019.
} 


\section{Defining Smart Cities}

Since the dawn of Smart City literature, a heated debate has raged even on the very definition of what a true Smart City really is (Hollands 2008). Vallianatos (2015) extends the timeline of "smart cities" and "big data" efforts by a considerable amount - all the way back to the late 1960s. "Beginning in the late 1960s and through most of the 1970s, the little-known Community Analysis Bureau used computer databases, cluster analysis, and infrared aerial photography to gather data, produce reports on neighborhood demographics and housing quality, and help direct resources to ward off blight and tackle poverty" (ibid.).

Over time, several definitions of the concept of Smart City have emerged, each differing in terms of the main smart characteristic deemed as the most relevant to define the very notion of urban smartness. Initial conceptualizations revolved around ICTs as the main pillar around which a city should build its smart pathway.

Earlier definitions related to the concept include the "wired city" (Dutton et al. 1987), whereby the focus is on networking the urban space per se and the "intelligent city" (Komninos 2009), which expands this idea by considering also the cognitive element of a digital city and the relationship between individual cognitive skills and the urban information system.

Linking smartness to the availability, development and use of ICT is based on the idea that, in order to succeed, cities and urban dwellers must be interconnected. The focus on ICTs and data availability is also related to a policy shift from mainly top-down to increasingly more bottom-up approaches, paving the way for greater importance of citizens' direct participation in the urban governance and their links with city officials.

This latter aspect is related to the importance of e-government in the creation of a Smart City (Deakin and Al Waer 2011). This in turn suggests an important role for the human capital component of cities and might also give rise to concerns related to the availability, management and privacy issues linked to big data (Batty 2012).

The vision of ICT-centered smartness eventually spurred several academic projects and research, not without critique against the strong business orientation of this concept. In fact, ICTs have been from the very inception of this concept considered at the roots of urban smartness, mostly because of the vast empirical evidence supporting ICT-led development (Caragliu 2013). This attracted the interest of large corporations, aiming at profiting from the interest of urban administrations in such technologies (Vanolo 2014).

Despite the relevant academic success and the significant investments in Smart City projects at all administrative levels, however, only a handful of works provide a clear-cut definition of what a Smart City really is, particularly by extending their characterization beyond the pure technological content, thus including contextual elements.

Because context elements are expected to co-explain the success of Smart City policies, only two notable definitions are mentioned (in chronological order), which 
truly go beyond ICTs as a means to define urban smartness, highlighting the most important elements.

Giffinger et al. (2007) provide a classification of European medium-size cities according to six axes (Smart people, Smart governance, Smart environment, Smart economy, Smart mobility and Smart living). Their definition reads as follows: " $A$ Smart City is a city well performing in a forward-looking way in these six characteristics, built on the 'smart' combination of endowments and activities of self-decisive, independent and aware citizens" (Giffinger et al. 2007, p. 13).

Caragliu et al. (2011) build on the classification by Giffinger and co-authors, providing a comprehensive and operational definition of urban smartness. In this case, cities are identified as smart when "investments in human and social capital and traditional (transport) and modern (ICT) communication infrastructure fuel sustainable economic growth and a high quality of life, with a wise management of natural resources, through participatory governance".

This definition presents two main advantages.

- It is inspired by an urban production function approach whereby urban smartness is defined as a precondition to urban economic performance;

- The definition decomposes the concept along six dimensions, which can be individually measured, using data from official sources. Therefore, this definition has been among the first to be empirically verified (Caragliu and Del Bo 2012).

In the rest of the paper, this last definition represents the foundations of all empirical estimates.

\section{Delimiting Smart City Policies}

While academics have actively participated in the debate about the definition of the concept of Smart City, they have relatively neglected the policy appraisal side.

Despite the non-negligible funding available at all spatial scales, albeit chiefly from the European Union through the SCC initiative, ${ }^{2}$ to date insufficient attention has been paid to a careful analysis of both the economic rationale for Smart City policies, as well as their potential growth-enhancing effects on cities.

Two major issues seem relevant for this analysis. On the one hand, Smart City policies must show some feature that makes this specific object of policy different from other axes of intervention. In other words, the economic rationale for Smart urban policies should be clarified. On the other hand, once the nature of such policies has been defined, their expected impact on urban growth should be discussed, with an eye on a possible empirical strategy to appraise the impact.

\footnotetext{
${ }^{2}$ It is worth stressing that this study focuses on European cities. Asian and US cities have experienced rather different paths towards urban smartness. In the USA, for instance, public-private partnerships (fostered among other entities by SmartAmerica, a White House Presidential Innovation Fellow project) foresee heavy involvement of private actors.
} 
On the first front, Smart Cities can be defined as the result of the interplay among the six axes of the Giffinger et al. definition. Vast theoretical work and empirical verifications are available on the role of human (Berry and Glaeser 2005) and social (Glaeser and Sacerdote 1999) capital; transport (Duranton and Turner 2012) and ICT (Basu et al. 2003) infrastructure; quality of life (Lenzi and Perucca 2018) and participatory governance (Rodriguez-Bolívar 2018) in urban development. Smart Cities are urban areas benefitting from a simultaneous engagement in all these six axes.

Recent evidence shows that Smart City policies are undertaken by urban areas that already score high in one or more of the axes of the definition used in this paper (Neirotti et al. 2014). Context factors, thus, not only enhance urban smartness, they also empower local dwellers and increase chances of success for Smart City policies.

From an economic perspective, our research has identified three main microfoundations for a positive policy impact to be expected:

- Smart City policies make cities more productive (Chourabi et al. 2012). For instance, Smart City policies have often stimulated the widespread availability of knowledge and information, especially in terms of big data (Kitchin 2015).

- Smart City policies enhance citizens' participation (Bakici et al. 2013). Participation of various social groups in the construction of Smart Cities is one of the most notable elements differentiating this concept from other similar notions found in the literature.

- Smart City policies offer increased business opportunities for local firms (Lee et al. 2014).

While some qualitative work on Smart City policy effectiveness has been carried out, a grand overview of the empirical association between Smart City policies in a cross-section of cities and urban performance is mostly absent. This translates into the following research question:

$R Q$. What is the economic impact of adopting Smart City policies on urban growth and innovation?

\section{Methods and Data for Policy Impact Assessment}

The research question of this paper faces a number of relevant empirical issues.

The two most relevant problems are related to the nature of Smart City policies impact (Do Smart City policies directly foster urban performance?), and the potentially relevant issue of endogeneity (Do Smart City policies foster urban performance, or is there selection bias?).

While there is very limited evidence of a direct causal impact of smart urban features on economic performance, individually taken, each axis of the adopted definition of urban smartness has been found to be positively associated with economic performance. Our work hinges on this finding (and tests it empirically) in order to 
identify the causal link between this type of policy and urban economic performance. The natural candidates for this type of econometric exercise are the instrumental variable (IV) and propensity score matching (PSM) estimators. ${ }^{3}$

As for the data employed in these analyses, in order to measure Smart City policy intensity, five main data sources on policy intensity have been analyzed:

- Cities implementing smart policies in the list prepared by the European Parliament (2014);

- Member cities of the Eurocities network;

- Cities participating in Framework Programme 7 Smart City initiatives;

- Cities actively cooperating with IBM for the deployment of Smart urban technologies;

- Member cities of the Lighthouse, ERRIN, and ICLEI networks.

Additionally, data have been collected to calculate the mean urban smartness indicator for a sample of $309 \mathrm{EU}$ cities based on the six dimensions of the definition in Caragliu et al. (2011). All the remaining data are collected at the EU metro area level, apart from the indicator of urban quality of institutions (Charron et al. 2015). This latter portion of the data is collected at NUTS2 level, and the value of each NUTS2 region is assigned to the metro area located in the region.

\section{Empirical Results}

Table 2 presents the empirical estimates discussed in Caragliu and Del Bo (2018). The estimates are presented in five columns, whereby additional control variables are added to highlight possible multicollinearity issues in the models tested. Column (5) is the preferred specification and suggests that a 16\% increase in Smart City policy intensity is associated with a $1 \%$ faster GDP growth. Our findings suggest a positive and statistically significant association between investing in Smart City policies and urban GDP growth. These estimates also suggest that this association is causal: Smart City policies foster economic performance, thus ruling out reverse causality.

Figure 2 graphically represents the main findings found in Caragliu and Del Bo (2019). This is obtained as follows. First, all patent applications to the European Patent Office from 2012 onwards have been geo-referenced and assigned to an EU metro area. Each patent application is assigned to one or more International Patent Class (IPC) codes, reflecting the nature of the technology characterizing the patent. ${ }^{4}$

Next, three sub-classes of patent applications have been identified, namely hightech patent applications, ICT patent applications and Smart City patent applications

\footnotetext{
${ }^{3}$ Owing to space limitations, most technical details are only briefly summarized here. For further analysis, the readers are invited to look into Caragliu and Del Bo $(2018,2019)$ where they will find a more thorough discussion regarding the technical details of the empirical estimates.

${ }^{4}$ When more IPC classes are available for each patent, the first has been used as the one characterizing the patent.
} 
Table 2 Smart City policies and urban GDP growth

\begin{tabular}{|c|c|c|c|c|c|}
\hline \multirow{2}{*}{$\begin{array}{l}\text { Dependent variable } \\
\text { Model }\end{array}$} & \multicolumn{5}{|c|}{ Metro area GDP growth rate, 2008-2013 } \\
\hline & (1) & (2) & (3) & (4) & (5) \\
\hline Constant term & $\begin{array}{l}0.08 * * * \\
(0.00)\end{array}$ & $\begin{array}{l}0.10 * * * \\
(0.00)\end{array}$ & $\begin{array}{l}0.24 * * * \\
(0.02)\end{array}$ & $\begin{array}{l}0.09 * * \\
(0.04)\end{array}$ & $0.02(0.03)$ \\
\hline $\begin{array}{l}\text { Initial per capita } \\
\text { GDP }\end{array}$ & $\begin{array}{l}-0.02 * * * \\
(0.00)\end{array}$ & $\begin{array}{l}-0.02 * * * \\
(0.00)\end{array}$ & $\begin{array}{l}-0.03 * * * \\
(0.00)\end{array}$ & $\begin{array}{l}-0.04 * * * \\
(0.00)\end{array}$ & $\begin{array}{l}-0.01 \\
(0.00)\end{array}$ \\
\hline $\begin{array}{l}\text { Intensity of Smart } \\
\text { City }\end{array}$ & $0.11 * * *$ & $023 * * *$ & $0.22 * * *$ & $024 * * *$ & $0.16 * * *$ \\
\hline Policies & $(0.00)$ & $(0.00)$ & $(0.00)$ & $(0.06)$ & $(0.06)$ \\
\hline Population density & - & $\begin{array}{l}-0.01 * * * \\
(0.00)\end{array}$ & $\begin{array}{l}-0.01 * * * \\
(0.00)\end{array}$ & $\begin{array}{l}-0.01 * * * \\
(0.00)\end{array}$ & $\begin{array}{l}-0.01 * * * \\
(0.00)\end{array}$ \\
\hline R\&D expenditure & - & - & $\begin{array}{l}0.03 * * * \\
(0.00)\end{array}$ & $\begin{array}{l}0.02 * * * \\
(0.00)\end{array}$ & $\begin{array}{l}0.02 * * * \\
(0.00)\end{array}$ \\
\hline $\begin{array}{l}\text { Quality of local } \\
\text { institutions }\end{array}$ & - & - & - & $\begin{array}{l}0.04 * * * \\
(0.01)\end{array}$ & $\begin{array}{l}0.04 * * * \\
(0.01)\end{array}$ \\
\hline $\begin{array}{l}\text { Dummy New } \\
\text { Member States }\end{array}$ & & & & & $\begin{array}{l}0.05 * * * \\
(0.01)\end{array}$ \\
\hline Number of obs. & 309 & 309 & 309 & 309 & 309 \\
\hline $\mathrm{R}^{2}$ & 0.26 & 0.28 & 0.28 & 0.29 & 0.32 \\
\hline Joint $\mathrm{F}$ test & $51.42 * * *$ & $30.94 * * *$ & $46.43 * * *$ & $40.32 * * *$ & $56.52 * * *$ \\
\hline Estimation method & IV & IV & IV & IV & IV \\
\hline $\begin{array}{l}\text { Variable } \\
\text { insturmented }\end{array}$ & \multicolumn{5}{|c|}{ Intensity of Smart City policies } \\
\hline Instruments used & \multicolumn{5}{|c|}{ Urban smartness; dummy, equal to 1 if the city is the Country capital } \\
\hline $\begin{array}{l}\text { Underidentification } \\
\text { test } \\
\text { (Kleibergen-Paap } \\
\text { rk LM statistic) }\end{array}$ & $46.13 * * *$ & $34.17 * * *$ & $34.03 * * *$ & $30.65 * * *$ & $2141 * * *$ \\
\hline $\begin{array}{l}\text { Weak identification } \\
\text { test (Cragg-Donald } \\
\text { Wald F statistic) }\end{array}$ & $50.47 * * *$ & $33.23 * * *$ & $32.61 * * *$ & $31.11 * * *$ & $1912 * * *$ \\
\hline $\begin{array}{l}\text { Hansen J statistic } \\
\text { (overidentification } \\
\text { test of all } \\
\text { instruments) }\end{array}$ & $19.24 * * *$ & $6.33 * *$ & 2.41 & 0.36 & 0.48 \\
\hline
\end{tabular}

Source Caragliu and Del Bo (2018)

Note Heteroskedastic-robust standard errors in brackets

$*, * *$, and $* * *$ indicate significance at the 90,95 , and $99 \%$, respectively 


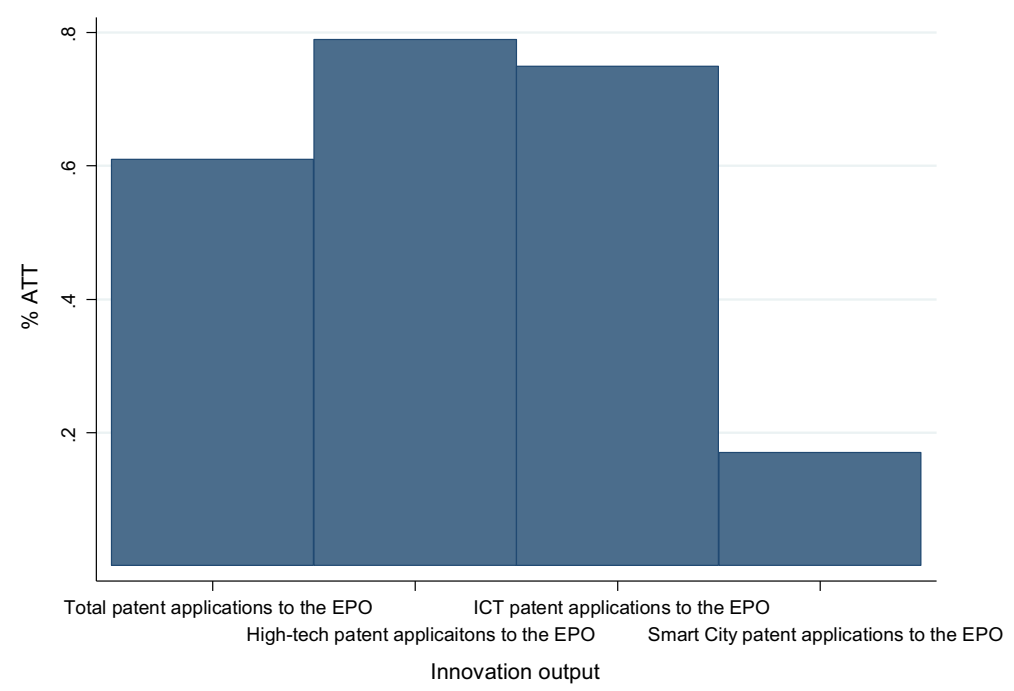

Fig. 2 Percentage average treatment effect on the treated cities. Source Caragliu and Del Bo (2019)

(IPO 2014). Finally, the sample of cities analyzed has been divided into those above and below the median intensity of Smart City policy intensity. PSM has been used to isolate the net impact of engaging in these policies on the innovation outcome described above.

Figure 2 suggests that the effects of Smart City policies are not limited to the most strictly defined IPC class of patents; rather, the impact is highest when looking at high-tech patents. Thus, an interesting spillover effect may be at play.

\section{Conclusions and Ways Forward}

This paper has provided a synthesis of the empirical work presented in Caragliu and Del Bo $(2018,2019)$ on the impact of Smart City policies on urban growth and innovation. Results suggest a statistically significant association between Smart City policies and the outcomes mentioned above; moreover, the use of advanced econometric techniques allows for inference in the causality direction of this link.

Yet, many more research questions relating to the economics of Smart Cities remain open.

First of all, the existence of a direct link between Smart urban features, and the possible synergic role they may play in stimulating economic growth, is yet to be inspected. Ideally, this exercise would require longer time spans in the data, in order to uncover possible long run effects that the database collected for this paper cannot capture. 
Moreover, a sound conceptual classification of existing Smart City policies could also be beneficial. The work here summarized is restricted by the limited availability of data concerning Smart City policy intensity, which could be overcome by a more formal definition of what makes a true Smart City for the policy provided.

Lastly, many criticisms have been discussed on the unequal effects that Smart City policies may have; for instance, benefitting the wealthy and educated, while causing a digital divide in the poor and uneducated segments of the population. This debate would greatly benefit from a sound empirical assessment of the impact of these policies on the intra-urban and intra-national distribution of resources.

\section{References}

Bakici T, Almirall E, Wareham J (2013) A smart city initiative: the case of Barcelona. J Knowl Econ 4(2):135-148

Basu S, Fernald JG, Oulton N, Srinivasan S (2003) The case of the missing productivity growth, or does information technology explain why productivity accelerated in the United States but not in the United Kingdom? NBER Macroecon Annual 18:9-63

Batty M (2012) Building a science of cities. Cities 29:S9-S16

Berry CR, Glaeser EL (2005) The divergence of human capital levels across cities. Papers Reg Sci 84(3):407-444

Caragliu A (2013) Dynamics of knowledge diffusion: the ICT sector in L ombardy. Reg Sci Policy Pract 5(4):453-473

Caragliu A, Del Bo C (2012) Smartness and European urban performance: assessing the local impacts of smart urban attributes. Innov Eur J Soc Sci Res 25(2):97-113

Caragliu A, Del Bo C (2018) The economics of smart city policies. Sci Reg 17(1):81-104

Caragliu A, Del Bo CF (2019) Smart innovative cities: the impact of Smart City policies on urban innovation. Technol Forecast Soc Chang 142:373-383

Caragliu A, Del Bo C, Nijkamp P (2011) Smart cities in Europe. J Urban Technol 18(2):65-82

Charron N, Dijkstra L, Lapuente V (2015) Mapping the regional divide in Europe: a measure for assessing quality of government in 206 European regions. Soc Indic Res 122(2):315-346

Chourabi H, Nam T, Walker S, Gil-Garcia JR, Mellouli S, Nahon K, Scholl HJ (2012) Understanding smart cities: an integrative framework. In: 2012 45th Hawaii international conference on system sciences, pp 2289-2297. IEEE

Deakin M, Al Waer H (2011) From intelligent to smart cities. Intell Build Int 3(3):140-152

Duranton G, Turner M (2012) Urban growth and transportation. Rev Econ Stud 79(4):1407-1440

Dutton WH, Blumler JG, Kramer KL (May 1987) Continuity and change in conceptions of the wired city. In: Wired cities: shaping the future of communications, pp 3-26. GK Hall \& Co

Giffinger R, Fertner C, Kramar H, Kalasek R, Pichler-Milanović N, Meijers E (2007) Smart cities. Ranking of European medium-sized cities. Centre of Regional Science of Vienna. www.smartcities.eu. Accessed 21 Dec 2014

Glaeser EL, Sacerdote B (1999) Why is there more crime in cities? J Polit Econ 107(S6):S225-S258

Hollands RG (2008) Will the real smart city please stand up? City 12(3):303-320

Intellectual Property Office (2014) Eight great technologies. The Internet of Things: a patent overview. https://www.gov.uk/government/publications/new-eight-great-technologies-internetof-things. Accessed 21 Nov 2017

Kitchin R (2015) Making sense of smart cities: addressing present shortcomings. Cambr J Reg Econ Soc 8(1):131-136

Komninos N (2009) Intelligent cities: towards interactive and global innovation environments. Int J Innov Reg Dev 1(4):337-355 
Neirotti P, De Marco A, Cagliano AC, Mangano G, Scorrano F (2014) Current trends in Smart City initiatives: some stylized facts. Cities 38:25-36

Lee JH, Hancock MG, Hu MC (2014) Towards an effective framework for building smart cities: lessons from Seoul and San Francisco. Technol Forecast Soc Chang 89:80-99

Lenzi C, Perucca G (2018) Are urbanized areas source of life satisfaction? Evidence from EU regions. Papers Reg Sci 97:S105-S122

Rodriguez-Bolívar PM (2018) Governance models and outcomes to foster public value creation in smart cities. Sci Reg 17(1):57-80

Vallianatos M (2015) Uncovering the early history of 'Big Data' and 'Smart City'in Los Angeles. Boom Calif. https://boomcalifornia.com/2015/06/16/uncovering-the-early-history-of-big-dataand-the-smart-city-in-la/. Accessed 2 May 2019

Vanolo A (2014) Smartmentality: the Smart City as disciplinary strategy. Urban Stud 51(5):883-898

Open Access This chapter is licensed under the terms of the Creative Commons Attribution 4.0 International License (http://creativecommons.org/licenses/by/4.0/), which permits use, sharing, adaptation, distribution and reproduction in any medium or format, as long as you give appropriate credit to the original author(s) and the source, provide a link to the Creative Commons license and indicate if changes were made.

The images or other third party material in this chapter are included in the chapter's Creative Commons license, unless indicated otherwise in a credit line to the material. If material is not included in the chapter's Creative Commons license and your intended use is not permitted by statutory regulation or exceeds the permitted use, you will need to obtain permission directly from the copyright holder. 